\title{
Koherensi dalam Novel Bumi Cinta Karya Habiburrahman El-Shirazy
}

\author{
Siti Sopiyahwati ${ }^{1}$, Sahrul Bachruddin² \& Goziyah $^{3}$
}

\author{
${ }^{123}$ Universitas Muhammadiyah Tangerang, Banten, Indonesia \\ ${ }^{1}$ sitisopiyahwati25@gmail.com, 2sahrulbachruddin67@gmail.com, \\ ${ }^{3}$ goziyah1812@gmail.com
}

\begin{abstract}
The research was conducted to provide information to readers about the importance of coherence in discourse. The coherence will make a discourse easy to read. The purpose of this study was to determine the use of coherence in "Bumi Cinta" by Habiburrahman El-Shirazy. The approach used is qualitative with content analysis methods. Data collection techniques using documentation techniques. The data analysis technique begins with data reduction, data tabulation, data classification, data interpretation, and conclusions. The data source used is a novel entitled "Bumi Cinta" by Habiburrahman El-Shirazy. The result of the research is that there are 26 sentences that have integration with each other. This novel contains elements of coherence, namely causal relationships, argumentative relationships, implicative relationships, generic-specific relationships, identifiable relationships, paraphrastic relationships, additive relationships, and relationships of yield relief.
\end{abstract}

Keywords: discourse analysis, coherence, novel, bumi cinta, habiburrahman el-shirazy

\begin{abstract}
Abstrak : Penelitian ini dilakukan untuk memberikan suatu informasi kepada pembaca mengenai pentingnya keberadaan koherensi dalam suatu wacana. Dengan adanya koherensi akan membuat suatu wacana menjadi indah untuk dinikmati. Tujuan penelitian ini untuk mengetahui penggunaan koherensi pada novel Bumi Cinta karya Habiburrahman El-Shirazy. Pendekatan yang digunakan yaitu kualitatif dengan metode analisis isi. Teknik pengumpulan data menggunakan teknik dokumentasi. Teknik analisis data dimulai dengan reduksi data, tabulasi data, klasifikasi data, interpretasi data, dan kesimpulan. Sumber data yang digunakan yaitu novel Bumi Cinta karya Habiburrahman El-Shirazy. Hasil dari penelitian ini adalah menemukan 26 kalimat yang memiliki keterpaduan satu sama lain. Novel ini mengandung unsur koherensi, yaitu hubungan sebab akibat, hubungan argumentatif, hubungan amplikatif, hubungan spesifik-generik, hubungan identifikatif, hubungan parafrastis, hubungan adiftif, dan hubungan kelonggaran hasil.
\end{abstract}

Kata Kunci : analisis wacana, koherensi, novel, bumi cinta, habiburrahman el-shirazy 


\section{Pendahuluan}

Wacana tidak akan terlepas dari koherensi, karena bagian kalimat satu dengan kalimat yang lainnya memiliki keterpaduan. Wacana merupakan unit bahasa yang terikat oleh suatu kesatuan bentuk dan makna yang direalisasikan dalam bentuk rangkaian kalimat-kalimat (Widiatmoko, 2015: 18). Menurut Goziyah (2018: 2) "Wacana adalah media komunikasi berbentuk lisan maupun tulisan yang dapat dipahami oleh komunikator (pembicara/penulis) dan komunikan (penyimak/pembaca). Hubungan rangkaian kalimat yang tersusun dalam suatu wacana harus selalu diperhatikan agar menjadi sebuah wacana yang utuh dan padu. Kepaduan atau keselarasan suatu wacana berkaitan dengan hubungan dan urutan antarkalimat dalam paragraf yang berfokus pada makna (Mandia, 2017: 178). Keseluruhan isinya pun harus saling mendukung guna memudahkan pembaca dalam memahaminya.

Koherensi merupakan salah satu syarat terpenting dalam suatu wacana. Alade dalam Utami, dkk (2019: 158) "Koherensi ialah unsur isi dalam wacana, sebagai organisasi semantik, wadah gagasangagasan disusun dalam urutan yang logis untuk mencapai maksud dan tuturan dengan tepat". Adapun Enkvist dalam Hasnah, dkk (2018: 222) mengatakan bahwa koherensi adalah kualitas tekstual yang membuat teks dapat ditafsirkan untuk pembaca dengan membangun dan menyesuaikan diri dengan gambaran dunia yang mungkin dan konsisten. Tujuan sarana koherensi ini ialah agar tercipta susunan dan struktur wacana yang memiliki sifat serasi, runtut, dan logis (Widiatmoko, 2015: 45).
Volume 3, Nomor 1, Januari 2021

ISSN 2655-3031 (P), 2655-7851 (O)

DOI: http://dx.doi.org/10.29300/disastra.v3i1.2963

Novel merupakan suatu wacana berbentuk naratif yang memiliki keterpaduan antarkalimat dalam paragraf. Sehingga memudahkan pembaca dalam menangkap suatu makna yang dibaca. Namun menurut Arifin (2013: 76) "Koherensi sebagai hubungan makna antar kalimat dalam sebuah wacana lebih sulit untuk dipahami, apabila pembaca tidak terbiasa dengan jenis teks tersebut". Akan tetapi, wacana jenis novel ini tergolong wacana yang mudah untuk dipahami, karena pemakaian diksi dalam wacana tersebut menggunakan bahasa yang umum ditelinga masyarakat. Kosasi dan Kurniawan (2019: 379) mengatakan bahwa novel adalah teks fiksi yang menceritakan kehidupan panjang satu atau beberapa orang tokoh dengan berbagai masalah di dalamnya.

Hasil penelitian relevan yang terkait dengan penelitian ini yaitu dilakukan Goziyah \& Insani (2018) dengan judul "Kohesi Dan Koherensi Dalam Koran Bisnis Indonesia dengan Judul Kemenperin Jamin Serap Garam Rakyat". Perbedaan antara penelitian ini terletak pada objek penelitian yaitu Koran Bisnis Indonesia dengan novel Bumi Cinta karya Habiburrahman ElShirazy, selain itu perbedaannya terletak pada apa yang dikaji, yakni kohesi, dan perbedaan selanjutnya terletak pada hasil temuan koherensi yang diteliti peneliti dengan hasil penelitian yang dilakukan oleh Goziyah \& Insani. Hasil yang ditemukan peneliti, yakni hubungan argumentatif, hubungan amplikatif, hubungan spesifikgenerik, hubungan identifikatif, hubungan parafrastis, hubungan adiftif dan hubungan kelonggaran hasil, sedangkan hasil yang ditemukan oleh Goziyah \& Insani, yakni hubungan pertentangan, hubungan perbandingan, hubungan tinjauan, dan hubungan rujukan. Adapun persamaan 
dalam penelitian ini terletak pada apa yang dikaji yaitu koherensi. Selain itu persamaannya juga terletak pada hasil temuan, yakni hubungan general spesifik, dan hubungan sebab-akibat.

Peneliti akan mengkaji unsur koherensi yang terdapat dalam novel Bumi Cinta karya Habiburrahman El-Shirazy. Dalam analisis koherensi, konteks keterpaduan isi dapat membantu pembaca dalam memahami suatu wacana dan membangun makna sesuai dengan interpretasi pembaca (Anjani, 2013: 296). Kepaduan isi wacana dalam suatu paragraf dinilai apabila suatu paragraf saling memiliki keterkaitan dapat dikatakan bahwa wacana tersebut sudah baik. Tujuan penelitian ini untuk mengetahui penggunaan koherensi pada novel Bumi Cinta karya Habiburrahman El-Shirazy.

Bumi Cinta merupakan novel karya Habiburrahman El-Shirazy. Novel ini mendapat respons positif dari publik dan kini sudah masuk cetakan ketiga. Di dalamnya menceritakan tentang seorang mahasiswa asal Indonesia yang sedang menyelesaikan pascasarjana di India. Habiburrahman ElShirazy adalah sastrawan dan cendekiawan Indonesia yang memiliki reputasi Internasional. Ia adalah sastrawan Asia Tenggara pertama yang mendapatkan penghargaan dari The Istanbul Foundation For Sciences And Cilture, Turki. Selain itu, budayawan dari Al Azhar University Cairo ini, telah mendapat berbagai penghargaan dari dalam dan luar negeri. Diantaranya: Penghargaan Sastra Nusantara Tingkat Asia Tenggara, Paramadina Award 2009, Anugerah Tokoh Persuratan dan Kesenian Islam Nusantara dari Ketua Menteri Negeri Sabah, Malaysia, Tokoh Perubahan dari Harian Republika.

\section{Metode Penelitian}

Metode penelitian menggunakan metode analisis isi dengan pendekatan kualitatif yang diarahkan pada analisis wacana koherensi. Sumber data dalam penelitian ini, yakni novel Bumi Cinta karya Habiburrahman El-Shirazy. Jenis data yang akan dianalisis yaitu berupa kutipan antarkalimat dalam paragraf yang memiliki koherensi. Teknik pengumpulan data menggunakan teknik dokumentasi, dimulai dengan reduksi data, tabulasi data, klasifikasi data, interpretasi data dan kesimpulan.

\section{Hasil dan Pembahasan}

Novel Bumi Cinta karya Habiburrahman El-Shirazy mengandung unsur koherensi. Unsur koherensi dalam novel tersebut ditemukan piranti di antaranya di antaranya hubungan sebab akibat, hubungan argumentatif, hubungan amplikatif, hubungan spesifik-generik, hubungan identifikatif, hubungan parafrastis, dan hubungan adiftif. Dalam pembahasan ini akan dijelaskan pada kutipan berikut:

\section{Hubungan Sebab Akibat}

"Mobil kusam merah tua itu terus melaju. Kecepatannya tidak bisa lebih dari enam puluh kilometer per jam".

Kedua kalimat di atas terlihat berbeda, namun memiliki keterpaduan. Kalimat pertama menjelaskan mobil merah tua yang kusam. Didukung kalimat kedua yang menjelaskan kecepatan mobil yang lambat. Dalam kalimat di atas juga menunjukkan adanya hubungan sebab akibat. Kata "Mobil kusam" pada kalimat pertama merupakan sebab, sedangkan kata "Enam puluh kilometer per jam" pada kalimat kedua merupakan akibat. Sebab 
mobil tersebut sudah kusam, sehingga akibatnya kecepatan lajunya melamban.

"Tahun lalu ada orang Filipina, teman aku, di puncak musim dingin dia tidak pakai penutup kepala yang lengkap. Daun telinganya biru beku”.

Kedua kalimat tersebut terlihat berbeda, namun memiliki keterpaduan. Kalimat pertama menjelaskan teman Devid yang berasal dari Filipina yang tidak memakai penutup kepala dimusim dingin tahun lalu. Didukung kalimat kedua yang menjelaskan tentang teman Devid yang kehilangan daun telingannya karena membiru beku. Dalam kalimat di atas juga menunjukkan adanya hubungan sebab akibat. Kata "Tidak pakai penutup kepala" pada kalimat pertama merupakan sebab, sedangkan kata "Biru beku" pada kalimat kedua merupakan akibat. Sebab pada musim dingin tidak memakai penutup kepala, sehingga akibatnya biru beku daun telingannya.

“Ayyas membuka tirai jendela. Kaca jendelanya yang tebal itu mengembun".

Kedua kalimat tersebut terlihat berbeda, namun memiliki keterpaduan. Kalimat pertama menjelaskan tirai jendela yang dibuka oleh Ayyas. Didukung kalimat kedua yang menjelaskan ketebalan kaca jendelan yang mengembun. . Dalam kalimat di atas juga menunjukkan adanya hubungan sebab akibat. Kata "Membuka tirai" pada kalimat pertama merupakan sebab, sedangkan kata "Mengembun" pada kalimat kedua merupakan akibat. Sebab tirai jendela di buka, sehingga mengakibatkan mengembun kaca jendela tebal itu.
"Pohon-pohon bereozka bergoyanggoyang. Salju yang menempel di daun-daunnya berguguran".

Kedua kalimat tersebut terlihat berbeda, namun memiliki keterpaduan. Kalimat pertama menjelaskan pohon bereozka bergoyang-goyang, karena hembusan angin. Didukung kalimat kedua yang menjelaskan salju menempel pada daun-daun pohon berezoka berguguran. Dalam kalimat di atas juga menunjukkan adanya hubungan sebab akibat. Kata "bergoyang-goyang" pada kalimat pertama merupakan sebab, sedangkan kata "berguguran" pada kalimat kedua merupakan akibat. Sebab pohon bereozka bergoyang-goyang, sehingga mengakibatkan salju yang menempel pada daun pohon bereozka berguguran.

\section{Hubungan Argumentatif}

"Kamar itu bernuansa biru. Indah, sejuk dan menyegarkan mata".

Kedua kalimat tersebut terlihat berbeda, namun memiliki keterpaduan. Kalimat pertama menjelaskan tembok kamar yang berewarna biru. Didukung kalimat kedua yang menjelaskan makna warna biru yang memiliki keindahan dan kesejukan yang dapat menyegarkan siapapun yang memandangnya. Dalam kalimat di atas juga menunjukkan adanya hubungan argumentatif. Kata "Biru" pada kalimat pertama merupakan pendapat, sedangkan kata "Indah, sejuk, dan segar" pada kalimat kedua merupakan argumentatif.

\section{Hubungan Amplikatif}

"Menurut Immanuel Kant, kebenaran adanya Tuhan adalah kebenaran postulat. Yaitu kebenaran tertinggi dalam tingkatan kebenaran". 
Kedua kalimat tersebut terlihat berbeda, namun memiliki keterpaduan. Kalimat pertama menjelaskan pendapat Immanuel Kant tentang kebenaran adanya Tuhan. Didukung kalimat kedua yang menjelaskan kebenaran adanya Tuhan yang dikemukakan oleh Immanuel Kant. Dalam kalimat di atas juga menunjukkan adanya hubungan amplikatif. Kata "Kebenaran postulat" merupakan gagasan pada kalimat pertama. Yang diperkuat dengan kalimat kedua pada kata "Kebenaran tertinggi".

"Ayyas melepas sepatunya dan melangkah masuk. Ruangan itu terasa hangat".

Kedua kalimat tersebut terlihat berbeda, namun memiliki keterpaduan. Kalimat pertama menjelaskan Ayyas yang melangkah masuk apartemen dengan melepas sepatu. Didukung kalimat kedua yang menjelaskan suasana apartemen yang hangat. Dalam kalimat di atas juga menunjukkan adanya hubungan amplikatif. Kata "Melangkah masuk" merupakan gagasan pada kalimat pertama. Yang diperkuat dengan kalimat kedua pada kata "Hangat".

"Ruang tamu itu menyatu dengan dapur yang rapi, yang sekaligus menjadi bar kecil. Di tembok dapur itu, gelas-gelas kaca berjejer rapi”.

Kedua kalimat tersebut terlihat berbeda, namun memiliki keterpaduan. Kalimat pertama menjelaskan ruang tamu dengan dapur apartemen yang menyatu. Didukung kalimat kedua yang menjelaskan gelas kaca yang diletakan ditembok dapur berjejer rapi. Dalam kalimat di atas juga menunjukkan adanya hubungan amplikatif. Kata "Dapur" merupakan gagasan pada kalimat pertama. Yang diperkuat dengan kalimat kedua pada kata "Gelas-gelas kaca berjejer rapi”".

"Ruang tamu itu cukup lega. Jarak lantai dengan langit-langit ruangan cukup tinggi”.

Kedua kalimat tersebut terlihat berbeda, namun memiliki keterpaduan. Kalimat pertama menjelaskan keadaan ruang tamun apartemen yang luas. Didukung kalimat kedua yang menjelaskan jarak lantai dengan atap. Dalam kalimat di atas juga menunjukkan adanya hubungan amplikatif. Kata "Lega" merupakan gagasan pada kalimat pertama. Yang diperkuat dengan kalimat kedua pada kata "Tinggi".

"Yelena sampai apartemen ketika salju kembali turun. Udara di luar apartemen perlahan-lahan bertambah dingin".

Kedua kalimat tersebut terlihat berbeda, namun memiliki keterpaduan. Kalimat pertama menjelaskan salju kembali turun setelah Yelena sampai di apartemen. Didukung kalimat kedua yang menjelaskan udara di luar apartemen yang semakin dingin. Dalam kalimat di atas juga menunjukkan adanya hubungan amplikatif. Kata "salju kembali turun" merupkan gagasan pada kalimat pertama. Yang diperkuat dengan kalimat kedua pada kata "bertambah dingin".

"Tubuh manusia sangat memerlukan air. Baik untuk minum atau pun untuk membersihkan kulitnya dari berjenis-jenis kotoran yang halus dan rumit".

Kedua kalimat tersebut terlihat berbeda, namun memiliki keterpaduan. Kalimat pertama menjelaskan pentingnya air bagi tubuh manusia. Didukung kalimat 
kedua yang menjelaskan berbagai manfaat air. Dalam kalimat di atas juga menunjukkan adanya hubungan amplikatif. Kata "air" merupkan gagasan pada kalimat pertama. Yang diperkuat dengan kalimat kedua pada kata "minum" dan "membersihkan kulitnya".

"Mata Yelena kembali menatap layar kaca yang menyiarkan terjadinya badai salju yang ekstrim di daerah Vyatka. Beberapa pohon tumbang dan ada rumah yang rusak parah".

Kedua kalimat tersebut terlihat berbeda, namun memiliki keterpaduan. Kalimat pertama menjelaskan Yelena sedang menonton televisi yang menyiarkan pemberitaan badai salju ekstrim yang terjadi di Vyatka. Didukung kalimat kedua yang menjelaskan tumbangnya pohon-pohon dan rusaknya rumah akibat badai salju ekstrim. Dalam kalimat di atas juga menunjukkan adanya hubungan amplikatif. Kata "badai salju" merupakan gagasan pada kalimat pertama. Yang diperkuat dengan kalimat kedua pada kata "pohon tumbang" dan "rumah yang rusak parah".

"Rasa khawatirnya semakin kuat. Atau jangan-jangan ia bertemu kelompok rasialis yang ekstrim, yang tidak menyukai bangsa ber-ras non Rusia”.

Kedua kalimat tersebut terlihat berbeda, namun memiliki keterpaduan. Kalimat pertama menjelaskan kekhawaritan Yelena pada Ayas. Didukung kalimat kedua yang menjelaskan sangkaan negatif Yelena kalau Ayyas bertemu dengan kelompok rasialis. Dalam kalimat di atas juga menunjukkan adanya hubungan amplikatif. Kata "khawatirnya" merupakan gagasan pada kalimat pertama. Yang diperkuat dengan kalimat kedua pada kata "bertemu kelompok rasialis".

"Begitu cepat suhu udara naik turun. Tadi pagi tujuh derajat, malam ini sudah lima belas derajat".

Kedua kalimat tersebut terlihat berbeda, namun memiliki keterpaduan. Kalimat pertama menjelaskan suhu udara yang tidak beraturan. Didukung kalimat kedua yang menjelaskan suhu udara pada pagi hari tujuh derat, sedangkan pada malam hari suhu udara mencapai lima belas derajat. Dalam kalimat di atas juga menunjukkan adanya hubungan hubungan amplikatif. Kata "suhu udara" merupakan gagasan pada kalimat pertama. Yang diperkuat dengan kalimat kedua pada kata "tujuh derajat" dan "lima belas derajat".

\section{Hubungan Spesifik-Generik}

"Di tengah jalan, ia sempatkan untuk mampir ke toko makanan milik orang Uzbekistan. Ia pesan nasi plof dengan lauk jamur, bubuk isi ikan smelt, kue kentang".

Kedua kalimat tersebut terlihat berbeda, namun memiliki keterpaduan. Kalimat pertama menjelaskan Yellena yang mampir ke toko makanan Uzbekistan. Didukung kalimat kedua yang menjelaskan Yellena membeli makanan untuk diberikan kepada Ayyas. Dalam kalimat di atas juga menunjukkan adanya hubungan spesifikgenerik. Kata "Toko makanan" pada kalimat pertama menyatakan gagasan umum atau luas, sedangkan kata "Nasi plof dengan lauk jamur, bubuk isi ikan smelt, kue kentang" pada kalimat kedua menyatakan gagasan khusus.

"Ayyas menutup pintu kamarnya, menyalahkan lampu kamar mandi, 
dan mengambil air wudhu. Ia langsung shalat menghadap kiblat".

Kedua kalimat tersebut terlihat berbeda, namun memiliki keterpaduan. Kalimat pertama menjelaskan Ayyas yang mengambil air wudhu. Didukung kalimat kedua yang menjelaskan Ayyas sedang melakukan ibadah shalat. Dalam kalimat di atas juga menunjukkan adanya hubungan spesifik-general. Kalimat pertama menyatakan gagasan umum, yakni pada kata "Menutup pintu", "Menyalahkan lampu", "Mengambil air wudhu". Sedangkan kalimat kedua menyatakan gagasan khusus, yakni pada kata "Shalat".

\section{"Devid mengeluarkan barang- barang dan makanan yang ia beli. Di antaranya membeli enam potong monti, daging giling yang dibalut tepung dan disiram mayonnese, dan dua wadah kentang goreng".}

Kedua kalimat tersebut terlihat berbeda, namun memiliki keterpaduan. Kalimat pertama menjelaskan Devid mengeluarkan barang serta makanan yang ia beli. Didukung kalimat kedua yang menjelaskan berbagai macam makanan yang dibeli Devid. Dalam kalimat di atas juga menunjukkan adanya hubungan spesifik-general. Kalimat pertama menyatakan gagasan umum, yakni pada kata "Mengeluarkan barang-barang dan makanan". Sedangkan kalimat kedua menyatakan gagasan khusus, yakni pada kata "Potong monti, daging giling yang dibalut tepung dan disiram mayonnese, dan dua wadah kentang goreng”.

\section{Hubungan Identifikatif}

"Di Singapura aku kenalan dengan mahasiswi dari Rusia, namanya Eva Telyantikova. Usianya lebih tua dariku, tapi sangat cantik".
Kedua kalimat tersebut terlihat berbeda, namun memiliki keterpaduan. Kalimat pertama menjelaskan bahwa Devid di Singapura berkenalan dengan Eva Telyantikova wanita Rusia. Didukung kalimat kedua yang menjelaskan usia Eva Telyantikova yang lebih tua dari Devid yang memiliki wajah yang cantik. Dalam kalimat di atas juga menunjukkan adanya hubungan identifikasi. Kata "Eva Telyantikova" pada kalimat pertama menyatakan gagasan, selanjutnya diidetifikasi dengan kalimat kedua pada kata "Tua" dan "Cantik".

\section{Hubungan Parafrastis}

"Sambil menyeret koper, Devid lalu mengajak Ayyas segera memasuki gedung apartemen tua yang dibangun zaman pemerintahan Stalin. Apartemen tua yang tetap nampak gagah itu terdiri atas lima lantai saja".

Kedua kalimat tersebut terlihat berbeda, namun memiliki keterpaduan. Kalimat pertama menjelaskan Devid dan Ayyas yang memasuki apartemen tua peninggalan pemerintahan Stalin. Didukung kalimat kedua yang menjelaskan kegagahan apartemen tua yang memilki lima lantai. Dalam kalimat di atas juga menunjukkan adanya hubungan parafrastis. Pada kalimat pertama menyatakan "David mengajak Ayyas memasuki gedung”. Diikuti kalimat kedua yang menyatakan lain pada kata “Tatap nampak gagah".

\section{Hubungan Adiftif}
"Devid telah memasukkan koper Ayyas ke dalam kamar dekat sofa panjang. Devid menghempaskan badannya ke sofa dan menghela nafas panjang". 
Kedua kalimat tersebut terlihat berbeda, namun memiliki keterpaduan. Kalimat pertama menjelaskan koper Ayyas yang diletakan di sofa panjang dalam kamar. Didukung kalimat kedua yang menjelaskan Devid yang sedang mengistirahatkan tubuhnya di sofa. Dalam kalimat di atas juga menunjukkan adanya hubungan adiftif. Pada kalimat pertama menyatakan "Memasukan koper", diikuti kalimat kedua "Menghempaskan badannya".

"Selesai mandi ia memakai pakaian yang hanya pantas dipakainya di dalam kamarnya saja. Hanya aurat terpentingnya yang benar-benar tertutup".

Kedua kalimat tersebut terlihat berbeda, namun memiliki keterpaduan. Kalimat pertama menjelaskan Yelena telah selesai mandi, lalu ia mengenakan pakaian dalam saja tanpa baju dan celana. Didukung kalimat kedua yang menjelaskan lengkukan tubuh Yelena yang hanya memakai pakai dalam saja. Dalam kalimat di atas juga menunjukkan adanya hubungan hubungan adiftif. Pada kalimat pertama menyatakan "pakaian", diikuti kalimat kedua menyatakan "aurat".

"Yelena duduk lalu rebahan di atas sofa panjang, kedua matanya terpaku pada layar kaca televisi. Sesekali tangan kanannya meraih gelas di atas meja berisi vodka martini".

Kedua kalimat tersebut terlihat berbeda, namun memiliki keterpaduan. Kalimat pertama menjelaskan Yelena sedang beristirahat di sofa sambil menonton televisi. Didukung kalimat kedua yang menjelaskan Yelena meminum vodka martini yang berada di atas meja. Dalam kalimat di atas juga menunjukkan adanya hubungan hubungan adiftif. Pada kalimat pertama menyatakan “duduk lalu rebahan”, diikuti kalimat kedua menyatakan "tangan kanannya meraih gelas".

"Yelena kembali duduk di sofa. Tibatiba bel berbunyi. Yelena terkesiap bahagia".

Ketiga kalimat tersebut terlihat berbeda, namun memiliki keterpaduan. Kalimat pertama menjelaskan Yelena duduk di sofa. Didukung kalimat kedua dan ketiga yang menjelaskan bunyi bel yang membuat Yelena bahagia. Dalam kalimat di atas juga menunjukkan adanya hubungan hubungan adiftif. Pada kalimat pertama menyatakan "duduk di sofa", diikuti kalimat kedua dan ketiga menyatakan "bel berbunyi" dan "bahagia".

"Listrik sempat mati selama empat jam. Tetapi pemerintah kota Vyatka terlihat sangat tanggap sehingga listrik mati tidak terlalu lama".

Kedua kalimat tersebut terlihat berbeda, namun memiliki keterpaduan. Kalimat pertama menjelaskan padamnya listrik selama empat jam yang diakibatkan oleh badai salju. Didukung kalimat kedua yang menjelaskan padamnya listrik di kota Vyatka tidak terlalu lama, karena tanggapnya pemerintah tersebut dalam mengatasinya. Dalam kalimat di atas juga menunjukkan adanya hubungan hubungan adiftif. Yang ditunjukkan pada kalimat pertama kata "Listrik" dan "mati", diikuti kalimat kedua yang ditujukan pada kata "pemerintah" dan "tanggap".

"Ayyas sudah memejamkan kedua matanya. Ia ingin segera lelap".

Kedua kalimat tersebut terlihat berbeda, namun memiliki keterpaduan. 
Kalimat pertama menjelaskan Ayyas tidur. Didukung kalimat kedua yang menjelaskan keingin Ayyas segera terlelap. Dalam kalimat di atas juga menunjukkan adanya hubungan adiftif. Yang ditunjukkan pada kalimat pertama kata "memejamkan" dan "matanya", diikuti kalimat kedua yang ditujukan pada kata "lelap".

\section{Hubungan Kelonggaran Hasil}

"Yelena bangkit ke kamarnya dan mengambil ponselnya. Ia mencoba menelpon Ayyas, tapi tidak bisa tersambung".

Kedua kalimat tersebut terlihat berbeda, namun memiliki keterpaduan. Kalimat pertama menjelaskan Yelena masuk kamar untuk mengambil ponsel miliknya. Didukung kalimat kedua yang menjelaskan Yelena menelpon Ayas, namun tidak tersambung. Dalam kalimat di atas juga menunjukkan adanya hubungan kelonggoran hasil, yang ditunjukkan pada kalimat kedua pada kata "tidak bisa tersambung".

\section{Simpulan}

Novel Bumi Cinta karya Habiburrahman El-Shirazy merupankan teks wacana yang memiliki keterpaduan atau keselarasan antarkalimat dalam paragrafnya. Setiap kalimat satu dengan kalimat yang lainnya memiliki makna yang utuh yang memudahkan pembaca untuk memahaminya. Hasil penelitian ini telah membuktikan bahwa analisis koherensi dapat digunakan untuk mengetahui keterpaduan antarkalimat dalam paragraf pada novel Bumi Cinta karya Habiburrahman El Shirazy. Hasil yang peneliti temukan 25 kalimat yang memiliki keterpaduan satu sama lain. Novel ini mengandung unsur koherensi, dalam novel tersebut ditemukan piranti, di antaranya hubungan sebab akibat, hubungan argumentatif, hubungan amplikatif, hubungan spesifik-generik, hubungan identifikatif, hubungan parafrastis, hubungan adiftif, dan hubungan kelonggaran hasil.

\section{Daftar Pustaka}

Arifin, Zaenal dkk. (2015). Wacana: Transsaksional dan Internasiaonal dalam Bahasa Indonesia. Tangerang: Pustaka Mandiri.

Anjani, Esa Agita. (2013). Kohesi Dan Koherensi Wacana Stand Up Comedy Prancis Dan Indonesia. Jurnal Kawistara. Universitas Gajdah Mada. Vol 3 No 3 Th 2013 Hal 288299.

https://jurnal.ugm.ac.id/kawistara/art icle/view/5223/4275

El Shirazy, Habiburrahman. (2019). Bumi Cinta. Jakarta: Republika.

Goziyah. (2018). Studi Wacana Bahasa Indonesia. Tangerang: UMT Press.

Goziyah dan Harninda Rizka Insani. (2018). Kohesi Dan Koherensi Dalam Koran Bisnis Indonesia Dengan Judul Kemenperin Jamin Serap Garam Rakyat. Jurnal Penelitian Pendidikan Bahasa Indonesia, Daerah, dan Asing. Universitas Muhammadiyah Tangerang. Vol 1 No 1 Th 2018 Hal 138.

Hasnah, dkk. (2018). Pewujudan Kohesi Dan Koherensi Pada Jurnal Refleksi Guru Bahasa Indonesia SMP Di Kabupaten Maros. Jurnal Ilmu Budaya. Universitas Hasanuddin Makassar. Vol 6 No 2 Th 2018 Hal 222.

Kosasi dan Kurniawan, Endang. (2019). 22 Jenis Teks dan Strategi Pembelajarannya di SMA-MA/SMK. Bandung: Yrama Widya.

Mandia, I Nyoman. (2017). Kohesi Dan Koherensi Sebagai Dasar 
Pembentukan Wacana Yang Utuh. Jurnal Sosial dan Humaniora. Politeknik Negeri Bali. Vol 8 No 2 Th 2017

Hal 14. http://ojs.pnb.ac.id/index.php/SOSH UM/article/view/531/492

Utami, dkk. (2019). Analisis Kohesi Dan Koherensi Pada Koran Solopos Dalam Artikel Mbok Mase Era Industri. Article University Research Colloqium.

Widiatmoko, Wisnu. (2015). Analisis kohesi Dan Koherensi Wacana Berita Rubrik Nasional Di Majalah Online Detik. Skripsi Universitas Negeri Semarang. 